\title{
Sustainability of higher educational buildings
}

\section{Retrofitting approach to improve energy performance and mitigate $\mathrm{CO}_{2}$ emissions in hot climates}

\author{
Mohsen Aboulnaga* and Mohamed Moustafa \\ Department of Architectural Engineering, Faculty of Engineering, Cairo University, Cairo, Egypt
}

\begin{abstract}
Despite greenhouse gases (GHG) emissions of Egypt represent nearly 1 percent of the World's GHG emissions, but according to IPCCC, Egypt is one of the nations that will be heavily affected by the impact of climate change risks. The global $\mathrm{CO}_{2}$ emissions from different sectors, buildings are forming the highest portion (about $5.5 \mathrm{GtCO}_{2}$-eq). Electricity consumption in public buildings, including administrative, educational and health buildings ( 9 percent) is the 2 nd largest type after residential buildings (40 percent). The electrical energy per person in Egypt has increased from $1245 \mathrm{kWh}$ in 2001/2002 to $1950 \mathrm{kWh}$ in 2012/2013; an increase of 57 percent. This resulted in a colossal amount of $\mathrm{CO}_{2}$ emitted into the atmosphere. Thus, improving energy performance in residential and higher education buildings will have a significant impact on the reduction of electrical energy use, improve recourses efficiency and the nation's economic growth and footprint. Energy consumption in education buildings depends, mainly on the building's activities, time of use and influx of visitors and students and academic staff as well as the academic terms whether in winter summer. Retrofitting measures are important to reduce energy consumption in higher educational buildings and cooling requirements in hot climate. One of the most important measures in the retrofitting process of the building envelop, including its roof are mainly glazing type and characteristics, and walls' thermal insulation. This paper addresses sustainability measures of the Faculty of Engineering Campus - Department of Architectural Engineering building at Cairo University, Egypt. The objective is to set the baseline assessment of the building' energy use and compared it with its energy performance after retrofitting measures and simulation. Results show that applying these retrofitting measures; energy use has been reduced by 15 percent from the baseline (BAU) energy use of an average of $14.6 \mathrm{kWh} / \mathrm{m}^{2}$ yearly.
\end{abstract}

\section{Introduction}

Cities including buildings worldwide are responsible for 60-80 percent of global energy use [1]. Buildings are responsible for about 33 percent carbon dioxide $\left(\mathrm{CO}_{2}\right)$ emissions [2]. Most of these emissions come from the combustion of fossil fuels to provide electrical energy in buildings for cooling, lighting, appliances and electrical equipment as well as heating water. In Egypt, public (educational, administrative and hospitals) and commercial buildings are responsible for more than 13 percent of the total electrical energy, whereas industrial and residential buildings account for 37 percent and 40 percent respectively as per 2013 [3]. Existing buildings form 34-40 percent of energy consumption in residential buildings [3]. Educational buildings are one of the buildings' types that are of great importance when it comes to energy consumption due to their pattern of occupancy and activities throughout the

\footnotetext{
* e-mail: mohsen_aboulnaga@yahoo.com
}

year. In the UK, building energy use associated with nondomestic buildings accounts for approximately 19 percent of the total $\mathrm{UK} \mathrm{CO}_{2}$ emissions [4,5]. Energy consumption in a non-domestic building is a complex issue due to a wide variety of uses and energy services and therefore the energy demands of individual buildings need to be understood. The carbon trust-the UK stated that a carbon reduction of 70-75 percent can be achieved in non-domestic buildings at no net cost [6]. Nevertheless, universities in the UK use significant amounts of energy [7,8] and according to new legislation [9], most of the UK's colleges and universities are now required to report on their energy use and improve their efficiency. This is not the case in Egypt. However, the energy demands behaviour in educational buildings, mainly universities is less well understood than other non-domestic buildings [10-12]. In another study that indicates almost 40 percent of the total energy consumption and 30 percent of $\mathrm{CO}_{2}$ emissions in the world is due to buildings [13].

Bahar Basarir et al. revealed that the energy efficient retrofit methods of the building envelopes of the school buildings were beneficial [14]. In the building sector, most of 
energy is used by existing buildings [15]. Nevertheless, the rate of replacement of existing buildings by new ones is relatively small, around $1-3$ percent yearly [15]. So, retrofitting of existing buildings is vital to reduce energy consumption especially in inefficient buildings. Governments around the world have taken bold measures towards existing buildings in terms of enhancing energy efficiency in existing buildings. In the USA, the Federal government offered finical assistance to support retrofitting existing buildings [16,17], whereas in Australia, the Commercial Buildings Disclosure (CBD) Programme asked owners to of large commercial office buildings to furnish energy efficient information to buyers and lesser $[18,19]$. In 2010, the UK government made a major commitment to upgrade the energy efficiency of 7 million British homes by 2020 with the intent to reduce $\mathrm{CO}_{2}$ emission by about 30 percent [20].

According to Mehreen Gul et al., reducing energy use is impossible without good data on which to make management and investment decisions [21]. She conducted a pilot study in 2013 to understand the energy consumption and occupancy of a multi-purpose post graduate centre (an academic building) at the School of the Built Environment at Heriot-Watt University in Edinburgh - Scotland, UK [21]. The study was undertaken to analyse the relationship between the electrical energy demand profiles and user activities for a university building. This pilot study has indicated that the building users have a small influence over the electrical consumption of the building. The study has also highlighted that the major source of electrical consumption is the heating/cooling systems of the building operated by a BMS, which is controlled by the University Estates department [21]. This study has additionally identified that the room occupancy has no significant effect on the electrical consumption of the building [21]. What this study has unearthed would not have been identified from a normal energy audit. Identifying gaps in terms of day-to-day operation of the building certainly has the potential to reduce energy consumption along with installing energy efficient equipment [21]. Another study by Fulvio Ardente et al. [22] presented the results of an energy and environmental assessment of a set of retrofit actions implemented in the framework of the EU Project "BRITA in PuBs" (Bringing Retrofit Innovation to Application in Public Buildings - no: TREN/04/FP6EN/S07.31038/ 503135). The outcomes arise from a life cycle approach focused on the following issues such as: (a) construction materials and components used during retrofits; (b) main components of conventional and renewable energy systems; and (c) impacts related to the building construction for the different elements and the whole building. The project highlighted the role of the life cycle approach for selecting the most effective options during the design and implementation of retrofit actions [23]. The Assessment outcomes indicated the most significant benefits were mainly related to the improvement of envelope thermal insulations, lighting and glazing [22].

In the International Energy Agency's (IEA) countries, educational buildings such as kindergartens, schools, training centres and universities exhibit various similar design, operation and maintenance features [24]. Many of these buildings have identical structures, often require to be retrofitted, and have high energy consumption. Due to the fact of the level of similarity that exists within this building sector, experiences gained in developing different approaches to combat identical problems, especially during retrofitting, can easily be transferred to other countries [24]. Nevertheless, retrofitting actions in Egypt, especially from the energy saving and energy efficiency is new concept and gained momentum in mid 2014 as a result of the electrical power shortage in summer and frequent cut due to load sharing. The retrofitting actions were mainly focusing on changing inefficient bulbs by CFL or LED, and in some governments building PV arrays were installed to generate electrical energy for the building during working hours. In general, this is not a holistic approach. The IEA's Energy in Buildings and Communities Programme (EBCP) published a report by Richard Barton, on the Annex 36 Retrofitting in Educational Buildings - Energy Concept Adviser for Technical Retrofit Measures (Faber Maunsell Ltd - UK, 2007), which indicated two significant similarities amongst these types of educational buildings that are (a) the high energy consumption; and (b) necessity to retrofit many buildings within this sector [24].

Sustainability and low-energy buildings are crucial strategies for meeting the challenge of enhancing the built environment to reduce energy consumption, lowering greenhouse gas (GHG), sustainable urban planning, including urban settings and building's envelop development to save electrical energy are essential issues in this research. In this paper, the Architectural Engineering Department building in the Faculty of Engineering in Cairo University was chosen as the case study. The Faculty of Engineering in Cairo University is located in the city center of Giza. The site surrounded by Cairo university road, Nahdet Misr Street and Giza zoo (Figs. 3 and 4). Improving energy performance in residential and higher education buildings will have a significant impact on reducing electrical energy consumption and enhance recourses efficiency and above all the nation's footprint. Energy efficient retrofit means ensuring the protection and maintenance of the cities and their components with innovative technologies and systems with the aim of reducing $\mathrm{CO}_{2}$ emissions and energy consumption associated with the built environment [14]. This work is intended to assess energy performance in an existing educational building. It is also part of the efforts to save energy and make buildings more energy efficient using retrofitting strategies to address Egypt's energy challenges.

\section{Objectives}

This paper aims at retrofitting of the Architectural Engineering building, a higher education building at Cairo University, Egypt, using simulation tools. Also determining the baseline assessment of the building' energy use and compared it with its energy performance after retrofitting measures and simulation.

\section{Methodology}

Retrofitting of existing buildings faces enormous challenges. One of which is uncertainties such as climate change, government policy variations. These may affect the 


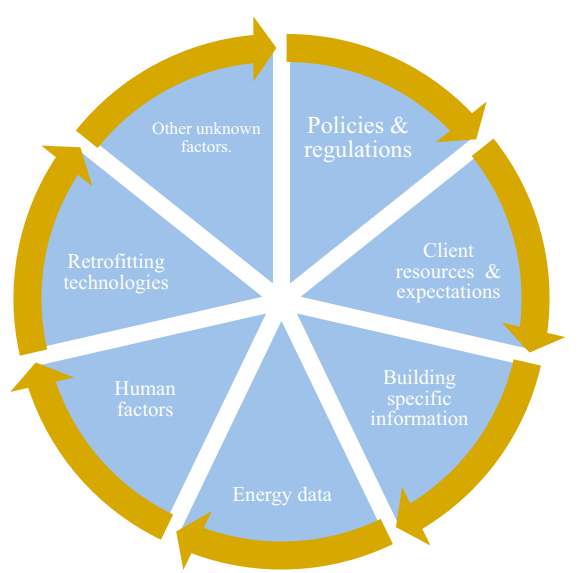

Fig. 1. Key elements affecting the retrofitting of buildings.

retrofitting technologies. The main elements impacting building retrofitting include main issues as shown in Figure 1. Key phases in a sustainable building retrofit programme are outlined by Zhenjun Ma et al. [15]. There are five phases involved in building retrofit. Figure 2 shows the five main phases. Energy audit (AE) is used to analyse building energy data, understand building energy consumption and identify the areas with excessive energy use and areas with energy wastes to suggest no cost and low costs approach in order to reduce energy consumption and retrofitting measures [15]. The EA is an investigation of energy use in a defined space in the building or the building as whole. It helps in identifying of energy use and costs from which energy costs and consumption control measures can be executed and reviewed [25]. Energy Audit varies in range and depth (ASHRAE Handbook and Australia/New Zealand standards [25-27]. Energy Audits are classified into three levels: (1) walk through assessment; (2) energy survey and analysis; and (3) detailed energy analysis [25-27]. Energy consumption in educational buildings depends mainly on the building's activities, time of use and influx of students, academic staff, and visitors as well as the academic terms whether in winter or in summer.

In this study, a theoretical approach was adopted based on available data. Energy simulation software "Design Builder" and "VeLux" were used to asses several parameters
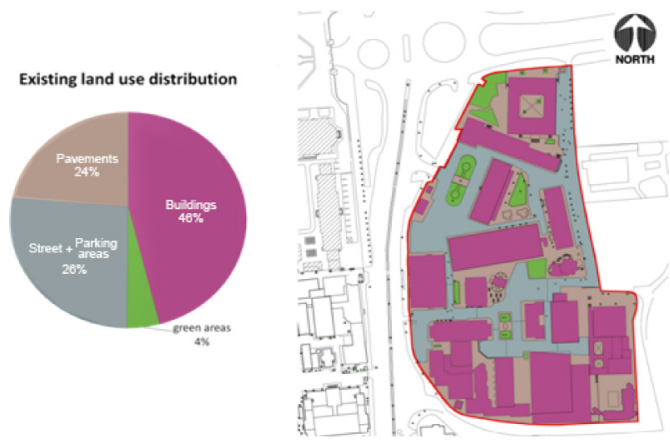

Fig. 3. Campus Land use showing percentage of Engineering buildings, street, parking \& Green areas.

of the building, including cooling and heating loads, energy consumption $\left(\mathrm{kWh} / \mathrm{m}^{2}\right)$ and daylighting distribution, so that appropriate measures can be exploited. The applied measures were re-simulated and results were compared with the baseline energy use to assess and find out the savings of the enhancement. In order to pursue the simulation, the process includes the following sequences.

\subsection{The campus land use distribution}

The Faculty of Engineering campus at Cairo University has 46 percent of its total areas buildings with conventional roofs setting, 26 percent local streets and parking areas; made of black asphalt with high solar absorptivity (more than 95 percent with very low solar reflective index), 24 percent pavements and only 4 percent of the site are green areas (Fig. 3). All leads to a 96 percent exposed urban surfaces of the site, surfaces that on a hot, sunny summer day, the sun can heat the roofs and pavements, to temperatures ranging from $30^{\circ} \mathrm{C}$ to $50^{\circ} \mathrm{C}$ hotter than the air surrounding these surfaces.

\subsection{Data gathering}

\subsubsection{The case study}

The building which houses the Architectural Department, Faculty of Engineering at Cairo University is the case study. The building architectural style is modern and it is

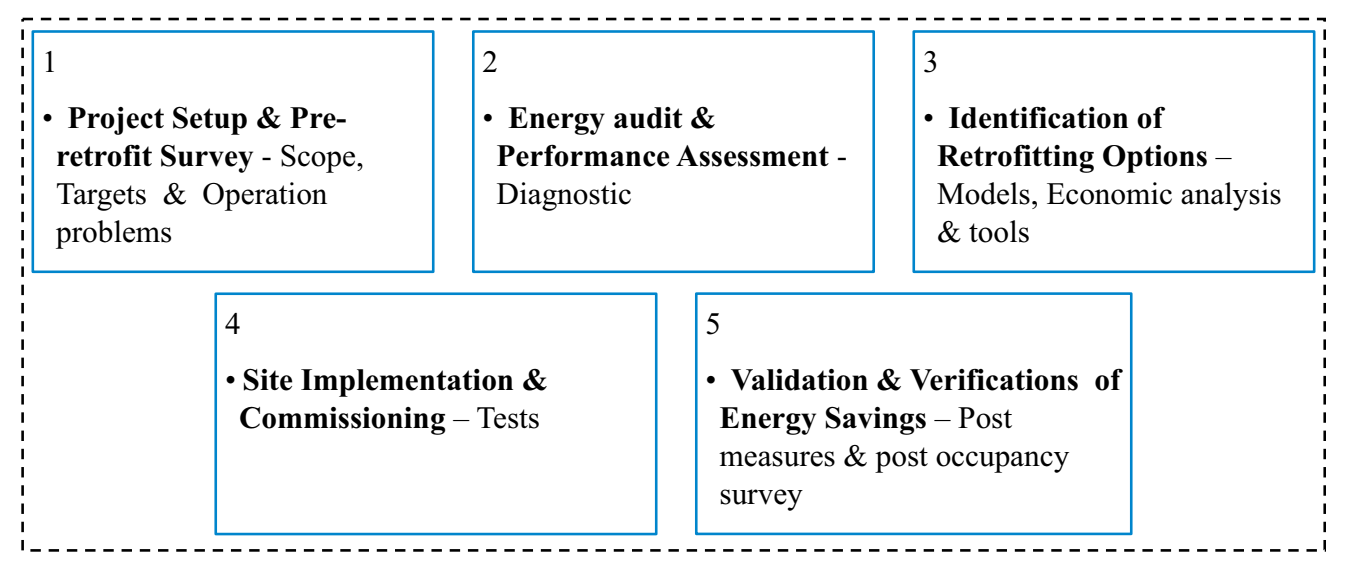

Fig. 2. Major phases used in a sustainable retrofitting process of buildings. 


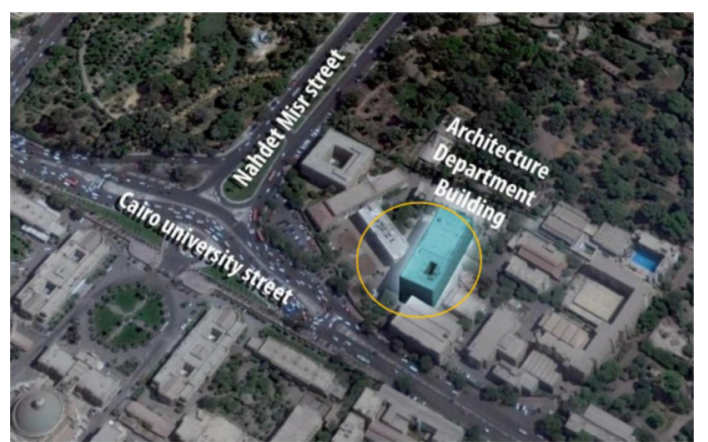

Fig. 4. Layout of Faculty of campus, Cairo University.

surrounded by low to medium-rise buildings. It consists of 8 storeys of which 4 storeys are occupied by Department of Architectural Engineering (3rd to 6th floors), and each one is $3.6 \mathrm{~m}$ high. The rest are used for different departments (2nd floor) is a computer ICT labs. The building was commissioned and used in 1989 (Fig. 4).

\subsection{Retrofitting process and measures}

This work focused on three folds: (a) developing simple prediction tools for retrofit concepts which allow the decision maker to evaluate integrated construction, installation and lighting measures; (b) developing a 'concept adviser' to analyse existing buildings and their economic efficiency, and to supplement this by simple methods for testing the efficiency of the applied measures; and (c) promoting energy and cost efficient retrofit measures and to support the decision makers in evaluating the efficiency and acceptance of available concepts. This study revealed that the development of an 'energy concept adviser' for economical retrofit measures is useful during the planning and realization phase. It was recommended that the 'adviser' should be applicable during the entire retrofitting phase to ensure that both the calculated energy savings and the economical success will be achieved after retrofitting [24].

\subsubsection{Building's envelope components}

The building envelope is all of the elements of the outer shell that maintain a dry, heated, or cooled indoor environment and facilitate its climate control. The building envelop components (exterior walls, fenestration, roof, ground floor) are shown in Figure 5. The building facades are modularly designed, so taking a section in one of the facades can determine its components.

\subsubsection{Building description and activities}

An energy audit (EA) was conducted for all floors. It started by a walkthrough assessment. The findings of the EA are as follows:

- Fifth floor: The total calculated Electrical use in the floor is $17,134.03 \mathrm{kWh}$,

- Fourth floor: The total calculated electrical energy use in the floor is $9027.3 \mathrm{kWh}$, and

- Second floor: The total calculated electrical energy use is $16,193.41 \mathrm{kWh}$.

\section{The BIM model}

A BIM model was created for the whole building in REVIT with the thermal properties gathered and assigned to the different building components (walls, fenestration, roof and floor), then the generated model was exported to "Design Builder" software, where climatic data assigned from US Department of Energy (DoE) weather files, and occupancy pattern were added.

\section{Baseline electrical energy consumption}

Baseline energy consumption was determined by several methods, including:

- Actual electrical energy consumption obtained from the bills were acquired, which indicated an average energy consumption of $8.59 \mathrm{kWh} / \mathrm{m}^{2}$;

- Manually calculated electrical energy consumption using occupancy patterns and appliances and equipment in each floor (e.g., 5th floor plan $7.60 \mathrm{kWh} / \mathrm{m}^{2}$ );

- Simulated results using Design Builder software (e.g., 5th floor plan $8.713 \mathrm{kWh} / \mathrm{m}^{2}$ );

- So that we can get valid results for the base model simulated in Design Builder by comparing its results with the manually calculated and energy bills.
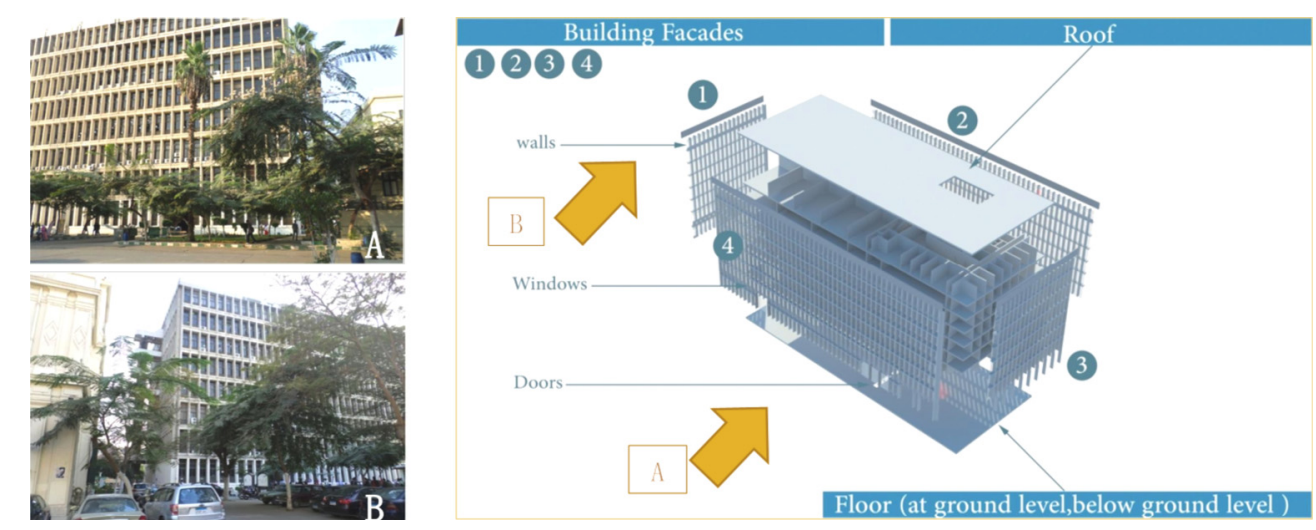

Fig. 5. The building envelop components. 

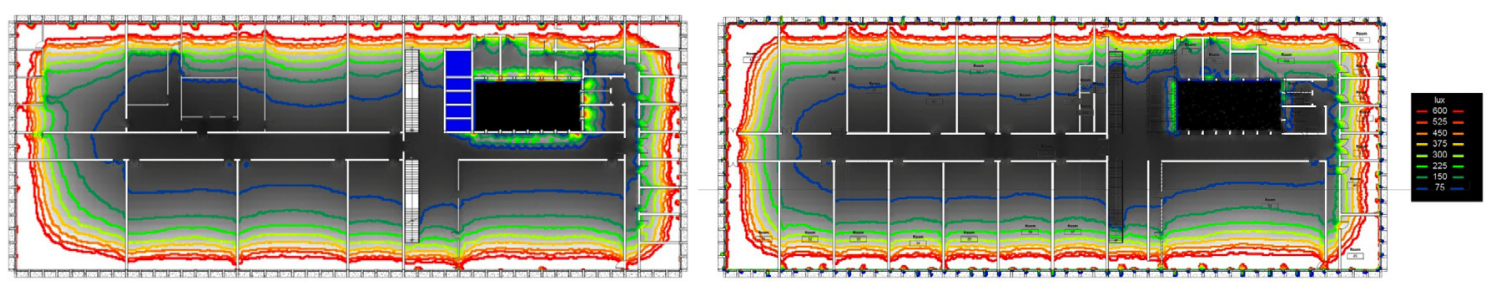

Fig. 6. Daylighting assessment of the Architectural Engineering building (3rd and 5th floor plans).

Table 1. Glazing characteristic of baseline, Case A and B.

\begin{tabular}{llll}
\hline Scenarios & $\begin{array}{l}\text { Baseline } \\
\text { Single glazing }\end{array}$ & $\begin{array}{l}\text { Case A } \\
\text { Low-E double glazing } \\
\text { filled with argon } \\
(13 \mathrm{~mm})\end{array}$ & $\begin{array}{l}\text { Case B } \\
\text { Changing single glazing } \\
\text { to low-E double glazing } \\
\text { filled with argon gas }\end{array}$ \\
\hline$U$-value $\left(\mathrm{W} / \mathrm{m}^{2} \mathrm{~K}\right)$ & 4.80 & 1.514 & 1.50 \\
Solar heat gain coefficient, SHGC & 0.81 & 0.595 & 0.33 \\
Visible light transmission, VLT & 0.89 & 0.769 & 0.38 \\
\hline
\end{tabular}

${ }^{a}$ Guardian SunGuard Super Neutral.

\section{Sustainability and retrofit measures}

Several retrofitting measures were applied to retrofit different floors of the building. These were used in the simulation of Case A and Case B. Also Case B was chosen to be applied to all floors, and after comparing its effectiveness on the 5th floors as summarised below.

\subsection{Daylighting assessment}

The building envelop has an effect on the amount of daylighting in interior spaces, so daylighting analysis was done using a simulation software "VeLux" to determine daylighting levels in interior spaces. Analysing the lighting levels in selected floor plans showed that Daylighting levels is not at its' recommended level throughout the spaces. For educational spaces, 400-500 lx are the optimum levels that must be achieved in classes and lecture halls [28]. This suggests that retrofitting is essential to achieve these optimum levels (Fig. 6).

\subsection{Glazing}

Single glazing with high solar heat gain coefficient (SHGC) of 0.81 and high $U$-values of $4.8 \mathrm{~W} / \mathrm{m}^{2} \mathrm{~K}$ that was replaced by a double glazing low-E glazing and re-simulation was done to determine the effectiveness of the change as shown in Table 1.

\subsection{External wall thermal insulation}

Thermal insulation for the building envelope was added o change the envelop section from the baseline (aluminum panel) of a $U$-value of $1.64 \mathrm{~W} / \mathrm{m}^{2} \mathrm{~K}$ to a compound wall (cases A and B) of overall $U$-value of $0.250 \mathrm{~W} / \mathrm{m}^{2} \mathrm{~K}$.
This compound wall layers includes external paint $2 \mathrm{~mm}$ on plaster applied on brick wall $(25 \mathrm{~cm})$, an air gap of $13 \mathrm{~mm}$, then a-12 mm Gibson board covered with calk and internal paint.

\subsection{Green roof}

Green roof (GR) was applied on the roof of the 7th floor to act as a heat insulator, plus its environmental advantages in lowering air temperature and minimise UHIE. Extensive GR type was used, so that low maintenance is needed and the current roof structure can withstand it.

\section{Results and discussion}

Electric energy consumption was determined using computer simulation software "Design Builder". The pattern for the total electric energy consumption per month for the fifth, fourth and second floors were calculated. This acts as a baseline for retrofitting. The measures applied for the retrofitting, including the changing of glazing characteristics to case B (Tab. 1) and upgrading the wall section to a multi layers wall with a $U$-value of $0.250 \mathrm{~W} / \mathrm{m}^{2} \mathrm{~K}$ instead of the aluminium wall section. In addition, a green roof was applied to the roof of the 7 th floor. The results of these retrofitting measures in the three different floors are shown in Figure 7. It indicates that most of the saving was found from the 7th floor due to application the green roof. Such saving was at $9107.25 \mathrm{kWh}$, which is about 29 percent. The saving in the electric energy consumption of the remaining floors with focuses on the 5th, 4th and 2nd floors are depicted in Table 2. According to simulations results, it is clear that the 5 th floor plan has the maximum saving of about $890 \mathrm{kWh}$, which is about 15 percent relative to its baseline consumption before retrofitting (most of 


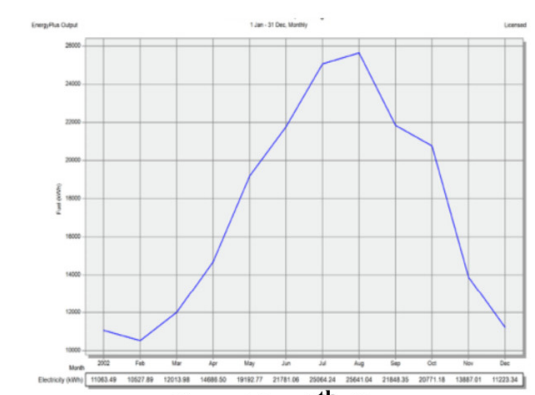

Case B $-5^{\text {th }}$ floor

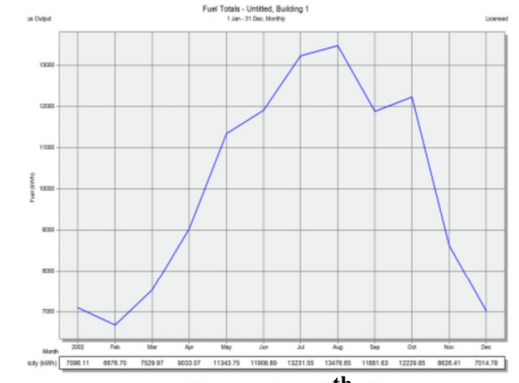

Case B $-4^{\text {th }}$ floor

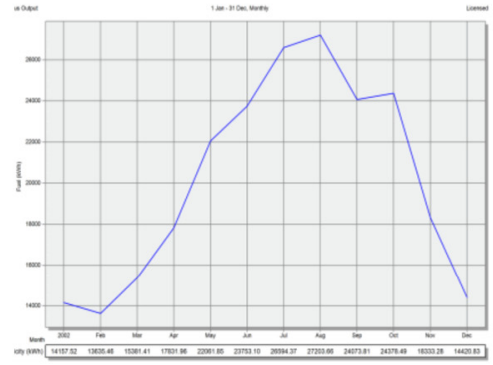

Case $B-2^{\text {nd }}$ floor

\begin{tabular}{|c|c|c|}
\hline $\begin{array}{c}\text { Average Total consumption/ month } \\
16735.63 \mathrm{kWh}\end{array}$ & $\begin{array}{c}\text { Average Total consumption/month } \\
10004.55 \mathrm{kWh}\end{array}$ & $\begin{array}{c}\text { Average Total consumption/ month } \\
16735.63 \mathrm{kWh}\end{array}$ \\
\hline Average consumption $/ \mathrm{month} / \mathrm{m}^{2}$ & Average consumption $/ \mathrm{month} / \mathrm{m}^{2}$ & Average consumption $/ \mathrm{month} / \mathrm{m}{ }^{2}$ \\
$7.42 \mathrm{kWh}$ & $3.96 \mathrm{kWh}$ & $9.29 \mathrm{kWh}$ \\
\hline
\end{tabular}

Fig. 7. The saving in electrical energy when applying Case B for the 5th, 4 th and 2nd floors.

Table 2. Results in energy saving of Case B.

\begin{tabular}{lll}
\hline Floor & $\begin{array}{l}\text { Saving of electric energy } \\
\text { consumption (percent) }\end{array}$ & $\begin{array}{l}\text { Actual saving } \\
\text { (kWh } / \text { month) }\end{array}$ \\
\hline 5 th & 15.00 & 890.37 \\
4 th & 9.40 & 939.44 \\
$2 \mathrm{nd}^{\mathrm{a}}$ & 4.00 & 769.85 \\
\hline
\end{tabular}

its spaces are air conditioned and at high occupancy hours). Thus, the retrofitting measures are most effective in reducing electric energy consumption due to less heat gains from the enhanced building fabric, while in the other floors; the saving in the 4th and 2nd floors was $939 \mathrm{kWh}$ and $769 \mathrm{kWh}$ respectively (Tab. 3). This forms about 9.40 percent (4th floor) and 4 percent (2nd floor) relative to their baselines before retrofitting. Figure 7 exhibited the

a The 3rd floor and 4 th floor are identical.

Table 3. Comparison of simulated, retrofitting, and energy savings - all floors.

\begin{tabular}{lccc}
\hline $\begin{array}{l}\text { Simulated electric } \\
\text { energy use }\end{array}$ & $\begin{array}{l}\text { Simulated electric energy } \\
\text { consumption }(\mathrm{kWh})\end{array}$ & $\begin{array}{l}\text { Retrofitting electric } \\
\text { energy kWh (simulated) }\end{array}$ & $\begin{array}{l}\text { Electric energy } \\
\text { saving (kWh) }\end{array}$ \\
\hline 7th floor & $30,865.33$ & $21,758.08333$ & 9107.25 \\
5th floor & $19,626.0$ & $16,735.63$ & 2890.37 \\
6th floor & $15,432.66$ & $12,879.03967$ & 2553.627 \\
Ground floor & 7850.4 & 6694.252 & 1156.148 \\
4th floor & $10,944.5$ & $10,004.55$ & 939.95 \\
1st floor & $10,944.5$ & $10,004.55$ & 939.95 \\
3rd floor & $10,944.5$ & $10,004.55$ & 939.95 \\
2nd floor & $20,922.29$ & $20,152.15$ & 770.14 \\
Total & $\mathbf{1 2 7 , 5 3 0 . 1 9}$ & $\mathbf{1 0 8 , 2 3 2 . 8 0 5}$ & $\mathbf{1 9 , 2 9 7 . 3 8 5}$ \\
& Percentage of saving & & 15.13 percent \\
\hline
\end{tabular}

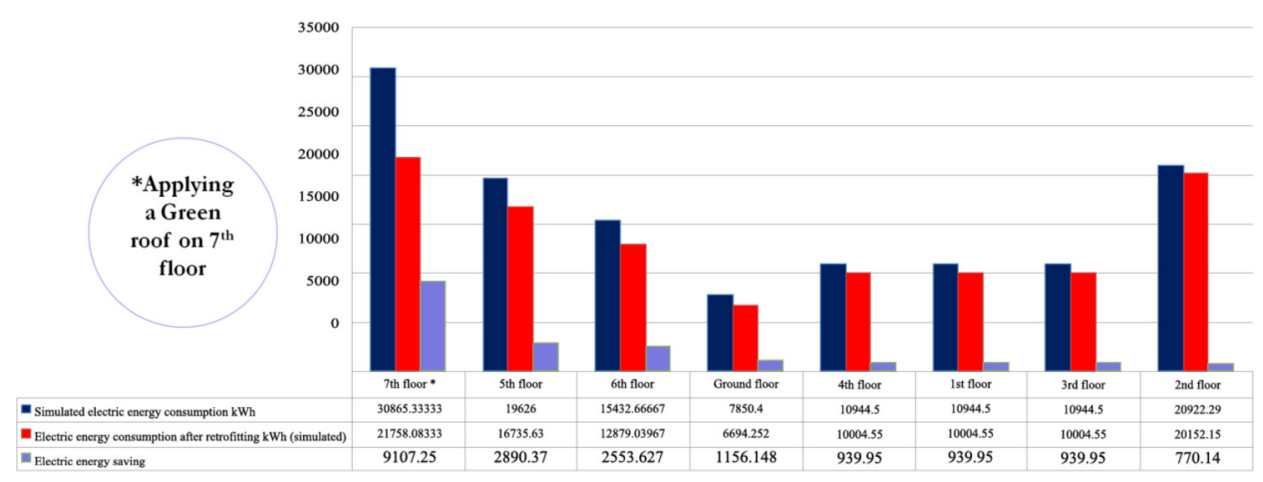

Fig. 8. Savings in energy use in all floors as a result of the retrofitting scenarios. 
saving in electrical energy when applying case B for the 5 th, 4 th and 2 nd floors. The comparisons of all floors are shown in Figure 8.

\section{Conclusions}

The retrofitting is vital for existing buildings to save energy and lower $\mathrm{CO}_{2}$. Results indicated that in Case B of all floors it was much better than Case A. Despite the changes in floor reduction due to activities, the overall reduction is about 15 percent from the baseline energy consumption. Changing the glazing to a low-E double glazing, with a $U$-value of $1.514 \mathrm{~W} / \mathrm{m}^{2} \mathrm{~K}$, SHGC of 0.595 and light transmission of 0.77 led to actual savings of $2317.6 \mathrm{kWh} /$ month from the baseline. The maximum saving was in the 7 th floor amounting to $9107 \mathrm{kWh}$ followed by the 5th floor. This is due the integration of the three measures, glazing, thermal insulation and green roof in the 7th floor. By changing the glazing to a low-E double glazing filled with argon and with a $U$-value of $1.50 \mathrm{~W} / \mathrm{m}^{2} \mathrm{~K}$, SHGC of 0.33 and a light transmission of 0.38 and $U$-vale of the enhanced wall of $0.25 \mathrm{~W} / \mathrm{m}^{2} \mathrm{~K}$ led to savings of 19,297 $\mathrm{kWh}$ from the baseline. Applying these retrofitting measures; the electrical energy use has been reduced by 15 percent from the baseline (BAU) energy use of an average of $14.6 \mathrm{kWh} / \mathrm{m}^{2}$ yearly.

\section{References}

1. United Nations Environmental Program (UNEP), Cities and buildings UNEP initiatives and projects (2012), p. 2: http://www.unep.org/SBCI/pdfs/Cities_and_BuildingsUNEP_DTIE_Initiatives_and_projects_hd.p.pdf, accessed June $20 \overline{16}$

2. C.H. Pout, F. MacKenzie, R. Bettle, Carbon dioxide emissions from non-domestic buildings: 2000 and beyond (BRE Energy Technology Centre, Watford, 2002)

3. Egyptian German High Level Joint Committee for cooperation on renewable energy and energy efficiency and environmental protection (JCEE): http://www.jcee-eg.net/, accessed May 2015

4. UK Green Building Council (UKGBC), Carbon reductions in existing non-domestic buildings (UK Green Building Council, London, 2011)

5. Department of Energy and Climate Change (DECC): https://www.gov.uk/government/policies/improvingthe-en ergy-efficiency-of-buildings-and-using-planning-to-protectthe-environment/supporting-pages/energyperformance-ofbuildings, accessed May 15, 2015

6. R. Liddiard, S. Taylor, M. Rylat, Characterising space use and electricity consumption in non-domestic buildings, in Proc. of Conference: IESD PhD Conference: Energy and Sustainable Development (Institute of Energy and Sustainable Development, De Montfort University, 2010)

7. T. Zhang, P. Siebers, U. Aickelin, Modelling electricity consumption in office buildings: an agent based approach, Energy Build. 43, 2882 (2011)

8. Research Councils UK: http//:www.rcukenergy.org.uk/.../re search-councils-energy-program.html, accessed May 15, 2015
9. European Commission Joint Research Centre: http://re.jrc.ec. europa.eu/energyefficiency $/ \mathrm{html} /$ standby_initiative_data_ centers.htm, accessed May 16, 2015

10. B. Bordass, R. Cohen, M. Standeven, A. Leaman, Assessing building performance in use 3: energy performance of probe buildings, Build. Res. Inform. 29, 114 (2001)

11. B.P.O. Gallachoir, M. Keane, E. Morrissey, J. O'Donnell, Using indicators to profile energy consumption \& to inform energy policy in a university: a case study in IrelandEnergy Build. 39, 913 (2007)

12. R. Yao, K. Steemers, A method of formulating energy load profile for domestic buildings in the UK, Energy Build. 37, $663(2005)$

13. O.S. Ozdil, 'Sürdürülebilir Yapılasma Sorunu ve Celik', Turk Yapısal Celik Dernegi: http://www.tucsa.org/images/yayin lar/makaleler/Surdurulebilir-Yapilasma-Sorunu-ve-Celik. pdf, accessed May 2015 (2010)

14. B. Basarir, B.S. Diri, C. Diri, Energy efficient retrofit methods at the building envelopes of the school buildings: http://www. salford.ac.uk/__data/assets/pdf_file/0015/142422/063Basarir.pdf, accessed May 18, $20 \overline{15}$ (2009)

15. Z. Ma, P. Cooper, D. Daly, L. Ledo, Existing building retrofits: methodology and state-of-the-art, Energy Build. 55, 889 (2012): http://www.sciencedirect.com/science/arti cle/pii/S0378778812004227, accessed May 15, 2015

16. DOR, DOE to Fund up to $\$ 454$ Million for Retrofit Ramp-Ups in Energy Efficiency: http://energy.gov/articles/doe-fund454-million-retrofit-ramp-ups-energy-efficiency, accessed May 21,2015

17. HUD, U.S.: http://portal.hud.gov/hudportal/HUD, accessed May 11, 2015

18. Australian Building Codes Board, Energy efficiency general information: http://www.abcb.gov.au/index. cfm?objectid=7384D70A-28B9-11DE-835E001B2FB900AA (2011)

19. Department of Climate Change and Energy Efficiency, Australian Government, Building Code of Australia: http://www.climatechange.gov.au/en/what-you-need-toknow/buildings/commercial/building code.aspx, accessed May 5, 2015 (2010)

20. DECC, Warmer homes, greener homes: a strategy for household energy management, UK Department of Energy and Climate Change: http//:www.decc.gov.uk, accessed May 7,2015

21. M.S. Gul, S. Patidar, Understanding the energy consumption and occupancy of a multi-purpose academic building, Energy Build. 87, 155 (2015)

22. F. Ardente, M. Beccali, M. Cellura, M. Mistretta, Energy and environmental benefits in public buildings as a result of retrofit actions, Renew. Sustain. Energy Rev. 15, 460 (2011)

23. http://www.ecbcs.org/annexes/annex36.htm, accessed May 26,2015

24. J. de Boer, IEA ECBCS Annex 36: Retrofitting of Educational Buildings - REDUCE, Energy Concept Adviser for Technical Retrofit Measures, International Energy Agency, Energy Conservation in Building \& Community: http://www.annex36.com/eca/uk/06util/pdf/ A36SubtaskC_Report_AuditProcedures.pdf, accessed May $26,2015(200 \overline{3})$

25. Standards Australia, Australia/New Zealand standard: Energy audits: (AS/NZ 3598:2000), Standards Australia International Ltd., and Standards New Zealand 2000, ISNB: 0733735762 
26. Standards Australia, Australia/New Zealand standard: Energy audits: Part 1 - Commercial buildings (AS/NZ 3598.1:2014), Standards Australia International Ltd., and Standards New Zealand 2000, ISNB: 9781775514992: http://shop.standards.co. nz/catalog/3598.1:2014(AS\%7CNZS)/scope?
27. ASHREA, ASHRAE handbook, HVAC application (ASHREA, Atlanta, 2011)

28. E.E. Richman, Requirements for Lighting Levels, Pacific Northwest National Laboratory: https://www.wbdg.org/ pdfs/usace_lightinglevels.pdf, accessed April 8, 2015

Cite this article as: Mohsen Aboulnaga, Mohamed Moustafa, Sustainability of higher educational buildings, Renew. Energy Environ. Sustain. 1, 28 (2016) 